\title{
ABCA2 wt Allele
}

National Cancer Institute

\section{Source}

National Cancer Institute. ABCA2 wt Allele. NCl Thesaurus. Code C89024.

Human ABCA2 wild-type allele is located in the vicinity of $9 q 34$ and is approximately $22 \mathrm{~kb}$

in length. This allele, which encodes ATP-binding cassette sub-family A member 2

protein, may play a role in the mediation of cholesterol transport, and neural

development. 